\title{
INSTANT STEM CELL THERAPY: CHARACTERIZATION AND CONCENTRATION OF HUMAN MESENCHYMAL STEM CELLS IN VITRO
}

\author{
P. Kasten ${ }^{1 *}$, I. Beyen ${ }^{1}$, M. Egermann ${ }^{1}$, A.J. Suda ${ }^{1}$, A.A. Moghaddam², G. Zimmermann², R. Luginbühl ${ }^{3}$ \\ ${ }^{1}$ Orthopaedic Surgery Hospital, University of Heidelberg, Schlierbacher Landstr. 200a, D-69118 Heidelberg, \\ Germany \\ ${ }^{2}$ Trauma Center Ludwigshafen, Ludwigshafen, Germany, \\ ${ }^{3}$ Dr. hc Robert Mathys Foundation, Bettlach, Switzerland
}

\begin{abstract}
In regenerative medicine, there is an approach to avoid expansion of the mesenchymal stem cell (MSC) before implantation. The aim of this study was to compare methods for instant MSC therapy by use of a portable, automatic and closed system centrifuge that allows for the concentration of MSCs. The main outcome measures were the amount of MSCs per millilitre of bone marrow (BM), clusters of differentiation (CD), proliferation and differentiation capacities of the MSC. A volume reduction protocol was compared to the traditional laboratory methods of isolation using a Ficoll gradient and native BM. Fifty millilitres of BM were obtained from haematologically healthy male Caucasians ( $n=10$, age 8 to 49 years). The number of colony forming units-fibroblast (CFU-F)/ml BM was highest in the centrifuge volume reduction protocol, followed by the native BM (not significant), the centrifuge Ficoll $(p=0.042)$ and the manual Ficoll procedure $(p=0.001)$. The MSC of all groups could differentiate into the mesenchymal lineages without significant differences between the groups. The CD pattern was identical for all groups: CD13+; CD 44+; CD73 +; CD90+; CD105+; HLAA,B,C+; CD14-; CD34-; CD45-; CD271-; HLA-DR-. In a further clinical pilot study ( $\mathrm{n}=5$ ) with $297 \mathrm{ml} \mathrm{BM}$ (SD 18.6), the volume reduction protocol concentrated the MSC by a factor of 14: there were $1.08 \times 10^{2} \mathrm{MSC} / \mathrm{ml} \mathrm{BM}$ (standard deviation (SD) $1.02 \times 10^{2}$ ) before concentration, $14.8 \times 10^{2}$ $\mathrm{MSC} / \mathrm{ml} \mathrm{BM}$ (SD $12.4 \times 10^{2}$ ) after concentration, and on average $296 \times 10^{2} \mathrm{MSC}$ (SD $248.9 \times 10^{2}$, range 86.4-691.5 $\mathrm{x} 10^{2}$ ) were available for MSC therapy. The volume reduction protocol of the closed centrifuge allows for the highest concentration of the MSC, and therefore, is a promising candidate for instant stem cell therapy.
\end{abstract}

Keywords: Stem cell; bone regeneration; osteogenesis; tissue engineering; therapy; isolation protocol.

*Address for correspondence:

Philip Kasten

Orthopaedic Surgery Hospital, University of Heidelberg, Schlierbacher Landstr. 200a, D-69118 Heidelberg, Germany

Telephone Number: $+49-6221-965$

FAX Number: +49-6221-96-6347

E-mail: Philip.Kasten@ok.uni-heidelberg.de
Introduction

The use of mesenchymal stem cells (MSC) is the principal part of the tissue engineering approach to regenerate tissue defects. MSC are contained in bone marrow (BM) aspirates in a concentration of approximately 10-100 MSC per $1 \times 10^{6}$ BM cells (Bruder et al., 1994; Campagnoli et al., 2001; Hernigou et al., 2005; Prockop et al., 2000; Wexler et al., 2003). For clinical use, e.g. to accelerate bone healing, high cell numbers are needed depending on the size of the bone defect (Bruder et al., 1998; Quarto et al., 2001). Therefore, it is necessary to efficiently isolate and retrieve MSC. Routinely, the mononuclear cell fraction that contains the MSC is isolated by centrifugation with a Ficoll gradient. This is a procedure done in a laboratory with the help of a laminar air-flow bench to avoid bacterial contamination. After isolation, the MSC can be expanded to high cell numbers in specialized laboratory units. For a clinical application, the omission of the expansion step of the cells would dramatically lower the costs and facilitate the use of MSC in hospitals that do not have the necessary laboratory facilities. A solution could be a procedure that separates a sufficient number of MSC from BM via a concentration step in the operating room. At the moment, the authors are not aware of any reports about a centrifuge that can be used in the operating room for orthopaedic purposes. Therefore, we compared a closed system centrifuge (Sepax, Biosafe, Eysins, Switzerland) that can run a volume reduction (SEPAX VOL RED) protocol to isolate the nuclear cell fraction (that contains the MSC) and a Ficoll (SEPAX FICOLL) protocol in a separate program to the manual open system laboratory Ficoll procedure (MANUAL FICOLL) and native BM (NATIVE).

The main outcome measures in the first phase were the amount of MSC per millilitres of native BM (assessed by the number of colony forming units-fibroblast (CFUF)), the capacity to differentiate into the adipogenic, chondrogenic and osteogenic lineages, and the analysis of the surface antigens of the cells (cluster of differentiation (CD)). In the second phase, the MSC yield and concentration capacity of the centrifuge by use of the SEPAX VOL RED protocol was evaluated in a clinical pilot study with higher volumes of bone marrow.

\section{Methods}

\section{Isolation of human mesenchymal stem cells}

Phase 1. According to the initial setting, $50 \mathrm{ml}$ of BM aspirate from the iliac crest were obtained from donors $(n=10)$ that received autogenous bone grafting under 


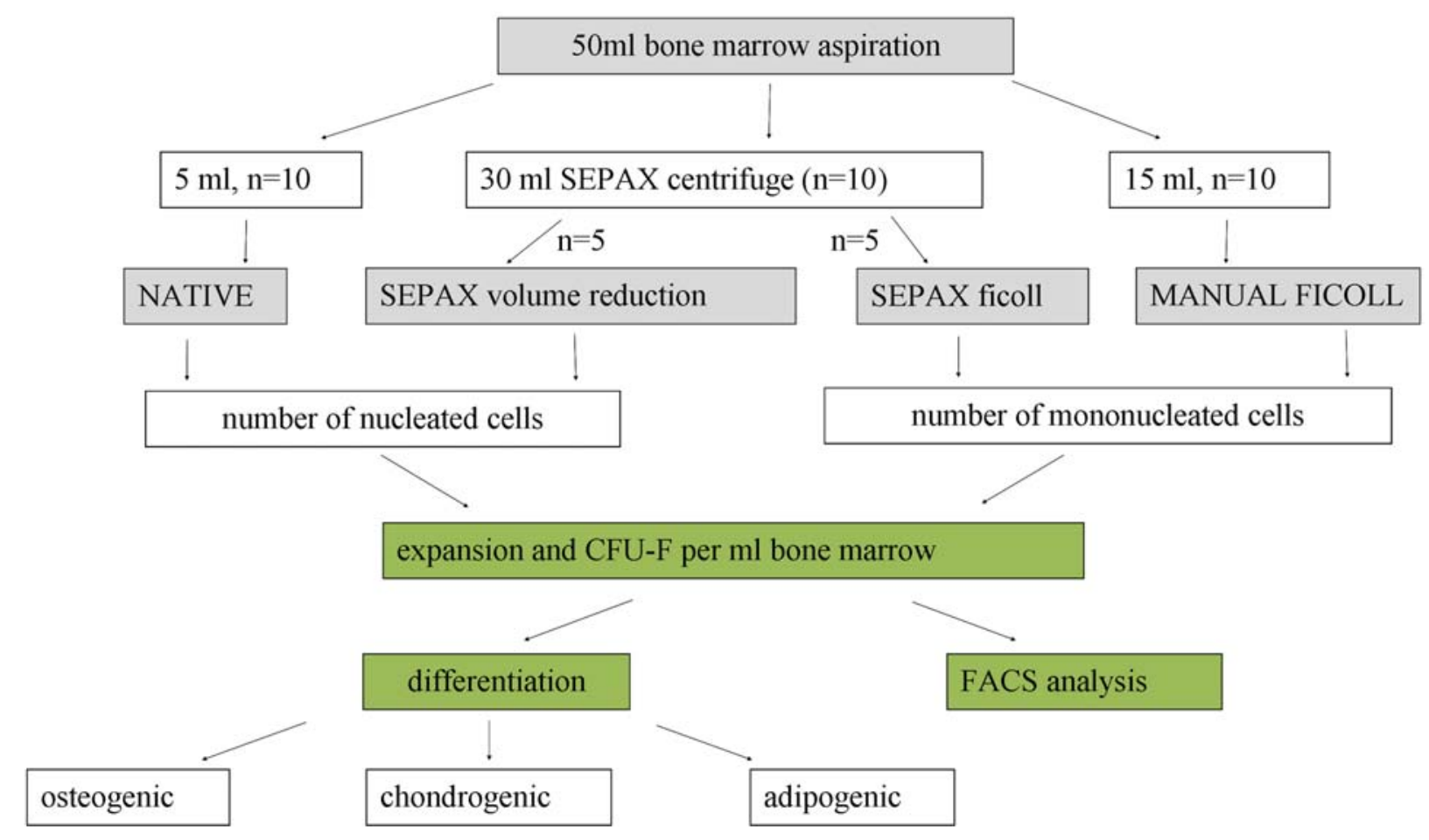

Figure 1: A flow-chart of the experimental setting of phase 1 is presented: the groups of SEPAX FICOLL, SEPAX VOL RED and the controls MANUAL FICOLL and NATIVE were compared.

general anaesthesia. All donors were haematological healthy male Caucasians ranging in age from 8 to 49 years (mean 24.3; standard deviation (SD) 14). Comorbidities affecting bone metabolism were not present. All procedures were approved by the institutional ethics committee and all donors provided informed consent. The fresh BM was mixed and divided into three parts (Fig. 1):

Thirty millilitres out of $50 \mathrm{ml} \mathrm{BM}$ were used for the closed SEPAX cell separation system (Biosafe, Eysins, Switzerland). The BM of five donors was processed by a volume reduction protocol (SEPAX VOL RED group) that isolates the NC fraction in the buffy coat. This protocol uses a single sedimentation step with $960 \mathrm{x} \mathrm{g}$ and concentrates the $\mathrm{NC}$ in a volume of $8 \mathrm{ml}$ output volume. The cell separation is permanently monitored by an optical sensor, fully automated and completed within 15 to 20 minutes. The $30 \mathrm{ml} \mathrm{BM}$ of the remaining 5 donors were processed with a Ficoll based separation protocol (SEPAX FICOLL group) that isolates the mononuclear cell (MNC) fraction. According to this protocol, 90ml FicollPaque $^{\mathrm{TM}}$ Plus (Amersham Biosciences Europe $\mathrm{GmbH}$, Freiburg, Germany) and 2 washing cycles with isotonic solution containing $2.5 \%$ bovine serum albumin (Sigma, Steinheim, Germany) were used. At the end of the automated procedure, the MNC fraction was delivered in an output volume of 45-50 ml. The resulting fraction of MNC was finally centrifuged in $90 \mathrm{ml}$ phosphate buffered saline (PBS) (10 min at $677 \mathrm{x} \mathrm{g}$ ) and re-suspended in $45 \mathrm{ml}$.

For the manual Ficoll procedure (MANUAL FICOLL group, $\mathrm{n}=10), 15 \mathrm{ml}$ out of $50 \mathrm{ml} \mathrm{BM}$ were washed two times in PBS (1:2) and centrifuged for 10 minutes at 677 $\mathrm{x} \mathrm{g}$. The resulting cell pellet was re-suspended in the initial volume of PBS and layered over $15 \mathrm{ml}$ Ficoll-Paque ${ }^{\mathrm{TM}}$ Plus.
This step was followed by a centrifugation for 30 minutes at $1524 \mathrm{x}$ g. The resulting fraction of mononuclear cells was recovered and washed in the double volume of PBS (10 $\mathrm{min}$ at $677 \mathrm{x} \mathrm{g}$ ).

The remaining $5 \mathrm{ml}$ out of $50 \mathrm{ml}$ native $\mathrm{BM}$ aspirate were not processed (NATIVE group, $n=10$ ).

Phase 2. Since high numbers of MSC are needed for a clinical application and the concentration capacity of the centrifuge is more efficient with higher volumes of bone marrow, the SEPAX VOL RED was tested in a pilot study with $n=5$ donors (mean age 47.4 , range 23-66 years, 4 men/ 1 woman) who received MSC therapy for fracture non-union (3x) or avascular necrosis of the femoral head (2x) (Fig 2). On average, $297 \mathrm{ml} \mathrm{BM} \mathrm{(SD} \mathrm{18.6)} \mathrm{were}$ aspirated from the iliac crest and reduced to an output volume of $18 \mathrm{ml}$ using the SEPAX VOL RED protocol. The amount of $\mathrm{NC}$ per $\mathrm{ml}$ of BM was examined before and after the centrifugation step.

\section{Yield of MSC after distinct cell isolation protocols}

The amount of nucleated cells in the SEPAX VOL RED and NATIVE groups and the number of MNC in the SEPAX FICOLL and MANUAL FICOLL groups were counted manually using a Neubauer chamber and Tuerk solution (Sigma).

Since MSC are characterized by their ability to adhere to plastic dishes, a standard protocol of counting the CFU$\mathrm{F}$ was used to assess the MSC yield of the different isolation procedures (Castro-Malaspina et al., 1980). In detail, triplicate aliquots of $1 \times 10^{6}$ cells were inoculated in 6 wells plates containing $2 \mathrm{ml}$ of culture medium according to Verfaillie with platelet derived growth factor (10 ng/ 


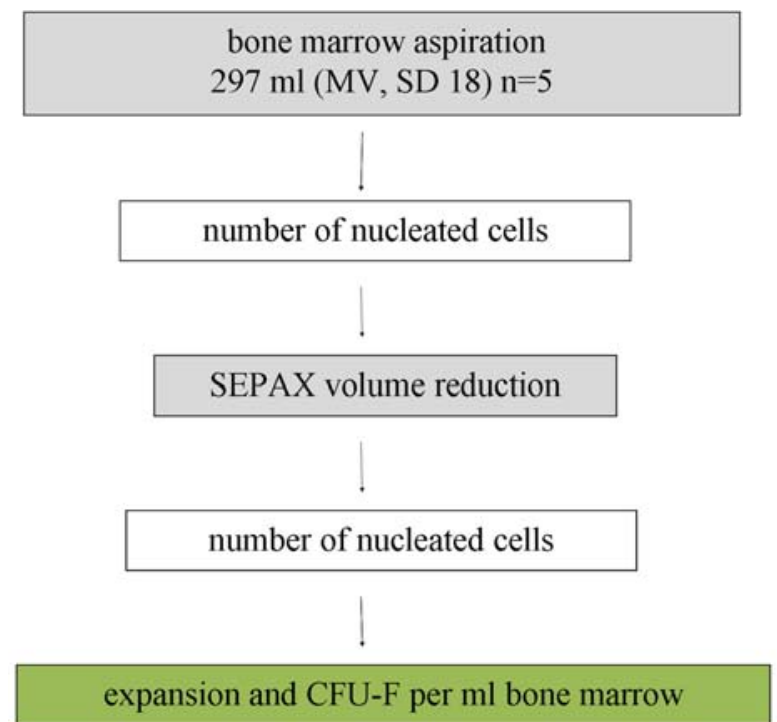

Figure 2: A flow-chart of the experimental setting of phase 2 is presented: in this separate setting the group of SEPAX VOL RED was evaluated with higher volumes of bone marrow.

$\mathrm{ml})$, epidermal growth factor $(10 \mathrm{ng} / \mathrm{ml})$ and $2 \%$ foetal calf serum (FCS) (Reyes et al., 2001). The cells were cultured under standard culturing conditions $\left(37^{\circ} \mathrm{C}, 6 \%\right.$ $\mathrm{CO}_{2}$ ). After $48 \mathrm{~h}$, non-adhesive cells were discarded and adhesive cells were washed once with PBS. The medium was completely exchanged on day 5 . On day 7 , the colonies were stained with toluidine blue and counted with a light microscope at $25 \mathrm{x}$ magnification. A cell aggregate of cells containing more than 50 cells was classified as a colony. The mean number of CFU-F was normalized to the initial volume of BM used in the distinct protocols.

For the phase 2 pilot study, the same protocol was used, but with the addition of $20 \%$ FCS to the expansion medium as published previously (Hernigou et al., 2005).

\section{Differentiation and characterisation of human MSC}

The capacity of the MSC to differentiate into the chondrogenic, osteogenic and adipogenic lineages was examined after passage 2 as published previously (Vogel et al., 2006).

For chondrogenic differentiation, micromasses of $1 \mathrm{x}$ $10^{6}$ cells were formed by centrifugation at $200 \mathrm{x} \mathrm{g}$ for 10min and kept for 28 days in chondrogenic differentiation medium. From each donor and for each group 2 pellets were formed. The medium contained 95.3\% DMEM high Glucose (Gibco Life Technologies; Invitrogen, Paisley, U.K.), 1\% ITS Supplement (Sigma), $0.1 \mu \mathrm{M}$ Dexamethasone (Sigma), 0.17mM Ascorbic acid-2phosphate (Sigma), $1 \mathrm{mM}$ Natriumpyruvat/ Sodiumpyruvate (Sigma), $0.35 \mathrm{mM}$ proline (Sigma), $1.25 \mathrm{mg} / \mathrm{ml} \mathrm{BSA}$ (Sigma) and 10ng/ml TGF $3-3$ (Sigma) (Winter et al., 2003). After one week of cultivation, micromasses were transferred to a 96-well U-bottomed plate to save medium. After 28 days micromasses were fixed for two hours in 4\% formaldehyde in PBS buffer (both by Merck, Darmstadt, Germany), washed with tap water, incubated in an ascending row of isopropanol, then in $100 \%$ acetone (each by Merck), and finally embedded in paraffin wax (Leica, Bensheim, Germany). Slices were cut in different depths of the pellets and stained with toluidine blue (Waldeck GmbH\&Co. KG, Division Chroma, Muenster, Germany). Immunohistochemistry was performed for collagen type I and II (antibodies by ICN, Aurora, Ohio, USA) (Winter et al., 2003); the secondary antibody was a biotinylated goat anti-mouse antibody (1:500). Sections were assessed by two blinded investigators using the same semi-quantitative histological score rating the amount of chondrogenic differentiation from 0 to 2: $0=$ no staining, $1=$ moderate, $2=$ well differentiated (Fig. 3).

For osteogenic differentiation in monolayer culture, 3.5 x $10^{4}$ cells were seeded in 24-well plates and each well received $500 \mu$ l osteogenic induction medium, containing DMEM high glucose, $10 \% \mathrm{FCS}, 100 \mathrm{IE} / \mathrm{ml}$ penicillin and $100 \mu \mathrm{g} / \mathrm{ml}$ streptomycin, $0.1 \mu \mathrm{M}$ dexamethasone, $10 \mathrm{mM}$ $\beta$-glycerolphosphate and $0.17 \mathrm{mM}$ ascorbic acid-2phosphate. The medium was changed every three days. After 14 days, the monolayers were harvested and stained with alizarin red-S (AR-S; Waldeck GmbH\&Co. KG, Division Chroma) (Stanford et al., 1995). In detail, monolayers were washed with PBS, fixed with $70 \%$ icecold ethanol, washed again with distilled water and stained for $10 \mathrm{~min}$ with AR-S. The surplus AR-S was removed by rinsing with distilled water. and bound AR-S was then quantified by incubation with cetylpyridinium chloride (CPC; Sigma, Taufkirchen, Germany). For dye elution, $200 \mu \mathrm{l}$ of $10 \%(\mathrm{w} / \mathrm{v}) \mathrm{CPC}$-solution in $10 \mathrm{mM}$ sodium

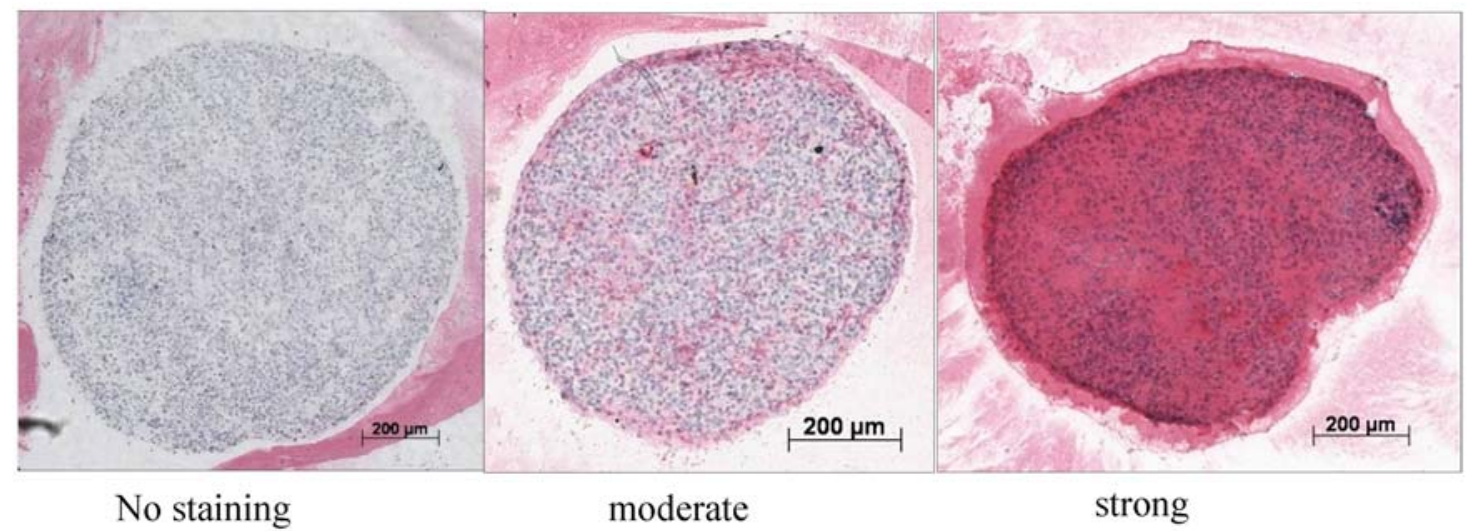

Figure 3: The pellets that were stained with collagen 2 were graded according to three categories: "no staining", "moderate staining", and "strong staining". 


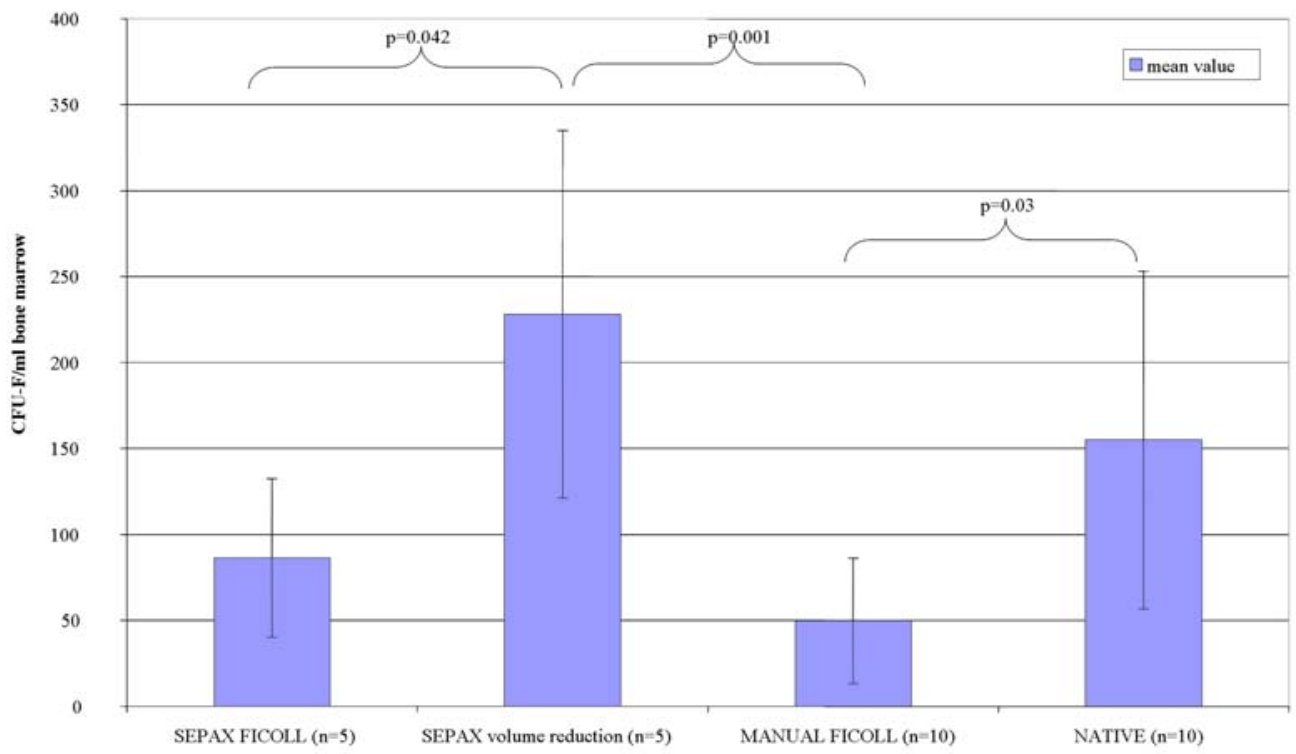

Figure 4: The amount of CFU-F that corresponds to the number of MSC was normalized to the initial volume of bone marrow. Besides the marked significances there were no significant differences present. Mean values and SD are shown.

(a)

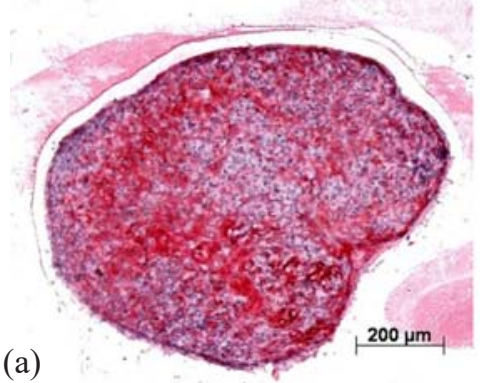

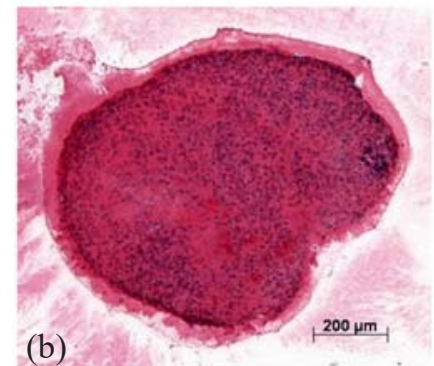

(c)

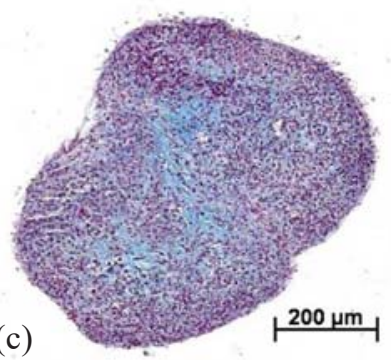

Figure 5: This exemplary set of pictures from the VOL RED group illustrates the the chondrogenic differentiation by collagen I, II immunostaining (a) \& (b), respectively, and alzian blue staining (c).

SEPAX FICOLL

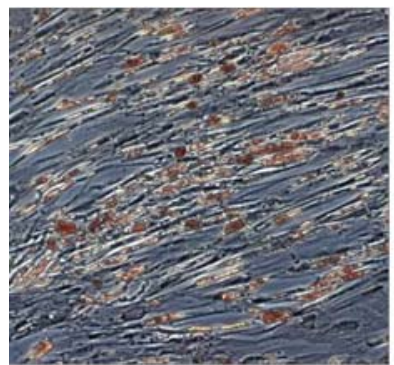

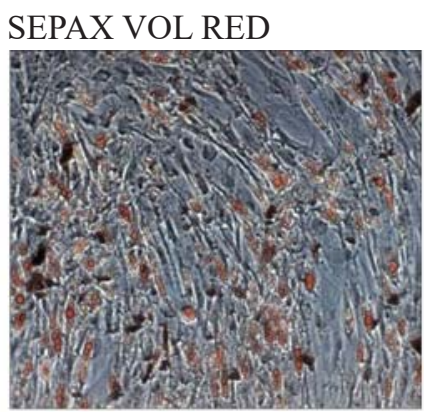

MANUAL FICOLL

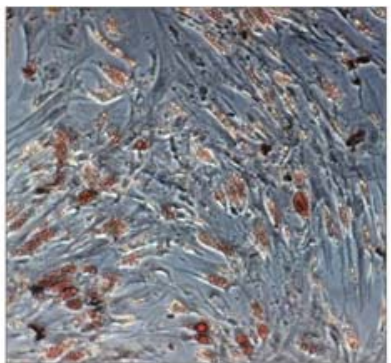

NATIVE

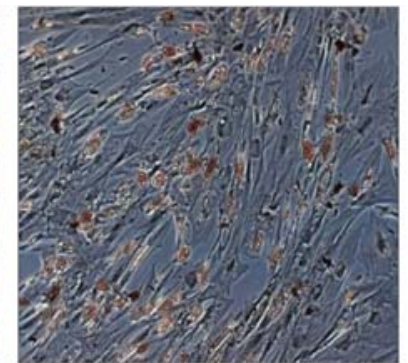

Figure 6: Adipogenic differentiation was assessed after 14 days by an oil-red-0 staining. There were no significant differences according to a semiquantative evaluation between the groups.

phosphate, $\mathrm{pH} 7$, were added to each well and incubated for $10 \mathrm{~min}(\mathrm{RT})$. The coloured solution of each well was then measured at $570 \mathrm{~nm}$ in an ELISA reader. Standards were prepared by diluting a $0.5 \%$ AR-S solution with CPCsolution.

For adipogenic differentiation in monolayer culture, the seeding procedure was the same as described for the osteogenic differentiation and cells were kept in adipogenic induction medium for 14 days (Winter et al., 2003). The adipogenic induction medium contained 86.6\% DMEM high glucose, 10\% FCS (Biochrom, Cambridge, U.K.), 1\% Penicillin/ Streptomycin (Biochrom), $1 \mu \mathrm{M}$ Dexamethasone, $0.01 \mathrm{mg} / \mathrm{ml}$ Insulin (Sigma), $0.2 \mathrm{mM}$
Indomethacin (Sigma) and $0.5 \quad \mathrm{mM}$ Isobutylmethylxanthine (Sigma).

For the evaluation of in vitro specimens by light microscopy, the adipogenic monolayers were fixed with $0.5 \%$ paraformaldehyde for $20 \mathrm{~min}$ at room temperature, then stained with $0.3 \%$ oil-red $\mathrm{O} / 60 \%$ isopropanol (Waldeck GmbH\&Co. KG, Division Chroma) and counterstained with hemalaun (Fa. Waldeck GmbH\&Co. $\mathrm{KG}$, Division Chroma) to mark the cell nuclei. Cells were examined by two independent blinded investigators at a magnification of $100 x$, using the following semiquantitative histological score from 0 to 4 : $0,0 \%$ cells stained positive for oil-red $\mathrm{O}(0 \%) ; 1+, 1-20 \%$ cells stained 
Table 1: Incidence of CFU-F / $\mathrm{ml}$ bone marrow

\begin{tabular}{|c|c|c|c|c|c|}
\hline outcome & variables & $\begin{array}{l}\text { mean value } \pm \\
\text { standard } \\
\text { deviation } \\
{[\mathrm{CFU}-\mathrm{F} / \mathrm{ml} \text { bone }} \\
\text { marrow }]\end{array}$ & $\begin{array}{l}\text { post-hoc- } \\
\text { comparison }\end{array}$ & $n$ & $\begin{array}{c}\text { ANOVA: Z-value/df/ } \\
\text { p-value }\end{array}$ \\
\hline \multicolumn{6}{|c|}{ Separation protocol } \\
\hline & SEPAX FICOLL & $86.2 \pm 46.21$ & $a, b$ & 5 & $7.129 / 3 / \mathrm{p}=0.001$ \\
\hline & SEPAX VOL RED & $228.06 \pm 106.94$ & $\mathrm{c}$ & 5 & \\
\hline & MANUAL FICOLL & $49.55 \pm 36.47$ & $\mathrm{a}$ & 10 & \\
\hline & NATIVE & $154.87 \pm 98.07$ & $\mathrm{~b}, \mathrm{c}$ & 10 & \\
\hline
\end{tabular}

Note: ${ }^{1)}$ The letter indicates significant differences between homogeneous subgroups at an alpha level of $5 \%$. That means for example, that the SEPAX FICOLL group (letters a and $b$ in the post hoc comparison) is not with in the $95 \%$ confidence interval of the SEPAX VOL RED group (letter c), but it is within the $95 \%$ confidence interval of the MANUAL FICOLL (letter a) and NATIVE (letters b and c) groups.

Table 2

\begin{tabular}{lccc}
$\begin{array}{l}\text { Chondrogenic differentiation } \\
\text { of the pellets }\end{array}$ & $\begin{array}{c}\text { SEPAX } \\
\text { FICOLL }\end{array}$ & $\begin{array}{c}\text { MANUAL } \\
\text { FICOLL }\end{array}$ & NATIVE \\
\hline no & $(2 / 17)$ & $(5 / 17)$ & $(9 / 19)$ \\
moderate & $(6 / 17)$ & $(9 / 17)$ & $(7 / 19)$ \\
good & $(9 / 17)$ & $(3 / 17)$ & $(3 / 19)$
\end{tabular}

positive; $2+, 21-50 \%$ cells stained positive; $3+, 51-80 \%$ cells stained positive; $4+, 81-100 \%$ cells stained positive.

\section{Fluorescence Absorbance Cell Sorting (FACS) analysis}

FACS analysis was performed using standard operating procedures and quantification criteria (Kasten et al., 2005): The gate to distinguish positive from negative cells was set individual for each marker, but was identical for each group. MSC at passage 3 and 4 were checked for the following $\mathrm{CD}$ with $1 \times 10^{4}$ cells for each marker: CD13; CD 44; CD73; CD90; CD105; CD271; HLA-A,B,C; CD14; CD34; CD45; HLA-DR.

\section{Statistics}

Mean values and standard deviations were calculated. The effect of the MSC isolation protocol was examined by multifactorial analysis of variance (ANOVA). Differences between the independent variables were checked in posthoc tests by QREG tests. The alpha error was consequently adjusted; $p$ values $<0.05$ were considered significant. All tests were two-tailed. Data analysis was performed with SPSS for Windows 12.0 (SPSS Inc., Chicago, IL, USA).

\section{Results}

\section{Phase 1}

The number of CFU-F/ml original bone marrow was highest in the SEPAX VOL RED group, followed by the NATIVE group (not significant) and the SEPAX FICOLL $(p=0.042)$ and the MANUAL FICOLL group $(p=0.001)$ (Fig. 4, Table 1).

The MSC of all groups could differentiate into the mesenchymal lineages. There were no significant differences regarding the histologic differentiation of the chondrogenic pellets (Table 2, Fig. 5). The native group seems to be inferior compared to the other groups without reaching significance.

The semiquantitative evaluation of the adipogenic differentiation displayed no significant differences (Fig. 6). Osteogenic differentiation displayed no significant difference between the groups (Fig. 7). There was a high donor variability, but no consistent difference between the groups.

The CD pattern was identical for all groups. The comparision of the SEPAX FICOLL, MANUAL FICOLL and the NATIVE group is shown in Table 3. The percentage of positive/ negative cells was similar between all groups. The VOL RED group had also the same CD pattern for all 5 donors: CD13+; CD 44+; CD73 +; CD90+; CD105+; HLA-A,B,C+; CD14-; CD34-; CD45-; CD271-; HLA-DR.

\section{Phase 2}

The SEPAX VOL RED protocol concentrated the MSC by a factor of 14 : there were $1.08 \times 10^{2} \mathrm{MSC} / \mathrm{ml} \mathrm{BM}$ (standard deviation (SD) $1.02 \times 10^{2}$ ) before concentration and $14.8 \times 10^{2} \mathrm{MSC} / \mathrm{ml} \mathrm{BM}$ (SD $12.4 \times 10^{2}$ ) after concentration. A mean of $296 \times 10^{2} \mathrm{MSC}$ (SD $248.9 \times 10^{2}$, range 86.4-691.5 $\times 10^{2}$ ) were available for MSC therapy. The NC content $/ \mathrm{ml} \mathrm{BM}$ was increased from $13.5 \times 10^{6}$ (SD 5.6) by a factor of 9.6 (SD 2) up to $128.5 \times 10^{6}$ (SD $60)$. There were $7.13 \mathrm{MSC} / 1 \times 10^{6} \mathrm{NC}$ (SD 3.4) before concentration and $10.72 \mathrm{MCS} / 1 \times 10^{6} \mathrm{NC}$ (SD 5.79) after concentration.

\section{Discussion}

Instant stem cell therapy is currently mainly under clinical investigation for cardiac and orthopaedic purposes (Gangji et al., 2004; Hernigou et al., 2002; Hernigou et al., 2005; Losordo et al., 2007; Nyolczas et al., 2007). The use of MSC without an expansion step relies on the separation 


\begin{tabular}{|c|c|c|c|c|c|c|c|c|c|c|c|c|}
\hline \multirow{3}{*}{$\overrightarrow{\dot{g}}$} & 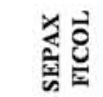 & $\stackrel{\circ}{\circ}$ & $\stackrel{\circ}{\square}$ & $\stackrel{\square}{\square}$ & $\stackrel{\circ}{\circ}$ & $\stackrel{\circ}{\square}$ & 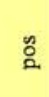 & 品 & $\stackrel{\circ}{\circ}$ & $\stackrel{\circ}{g}$ & 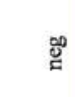 & : \\
\hline & 㿣 & $\stackrel{\circ}{\circ}$ & 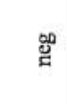 & 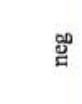 & $\stackrel{\circ}{\circ}$ & $\stackrel{\square}{\square}$ & $\stackrel{\circ}{\circ}$ & $\stackrel{\circ}{\circ}$ & $\stackrel{\text { : }}{\circ}$ & $\ddot{g}$ & ๕ొ & : \\
\hline & $\sum_{z}^{n}$ & 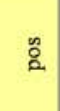 & $\stackrel{\infty}{\not 2}$ & $\stackrel{0}{\square}$ & $\stackrel{\text { ڤ. }}{2}$ & 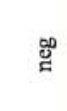 & $\stackrel{\circ}{\circ}$ & $\stackrel{\text { : }}{\circ}$ & $\stackrel{\circ}{\circ}$ & 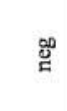 & ஜొ & $\stackrel{\circ}{\circ}$ \\
\hline \multirow{3}{*}{ 함 } & 通 & $\stackrel{\circ}{\circ}$ & 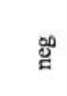 & 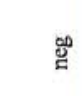 & $\stackrel{\circ:}{\circ}$ & $\stackrel{0}{:}$ & $\stackrel{\text { : }}{\circ}$ & : & : & 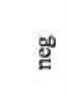 & 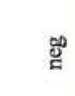 & : \\
\hline & 家 & $\stackrel{\circ}{\circ .}$ & $\stackrel{\approx 0}{\tilde{z}}$ & $\stackrel{0}{\rightleftarrows}$ & $\stackrel{\text { : }}{\circ}$ & $\stackrel{\square}{\rightleftarrows}$ & $\stackrel{\text { : }}{\circ}$ & : & : & $\ddot{~}$ & 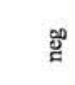 & : \\
\hline & $\sum_{\Sigma}^{m}$ & $\stackrel{\text { : }}{\circ}$ & 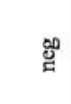 & 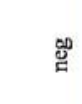 & $\stackrel{\text { : }}{\circ}$ & 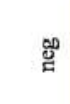 & 总 & 总 & $\stackrel{\text { : }}{\circ}$ & 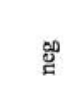 & ஜొ & $\stackrel{\text { g }}{\circ}$ \\
\hline \multirow{3}{*}{ 音 } & 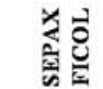 & $\stackrel{\circ}{\circ}$ & $\stackrel{\circ}{g}$ & $\stackrel{\varpi}{\square}$ & $\stackrel{\text { : }}{\circ}$ & $\stackrel{\circ}{g}$ & : & : & $\stackrel{\text { : }}{\circ}$ & $\ddot{g}$ & $\stackrel{\text { gొ }}{ }$ & : \\
\hline & 㝴 & 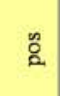 & $\ddot{~}$ & $\ddot{~ \rightleftarrows ొ ~}$ & $\stackrel{\circ}{\circ}$ & $\ddot{~}$ & : & $\stackrel{\circ}{\circ}$ & $\stackrel{\circ}{\circ}$ & $\ddot{~}$ & 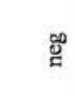 & $\stackrel{\circ}{\circ}$ \\
\hline & $\sum_{\Sigma}^{n}$ & 总 & $\stackrel{\circ}{g}$ & $\ddot{g}$ & $\stackrel{\text { : }}{\stackrel{\circ}{\circ}}$ & 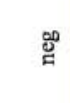 & 总 & 总. & $\stackrel{\circ}{\circ}$ & $\ddot{~}$ & $\stackrel{\text { gొ }}{\square}$ & 总 \\
\hline \multirow{3}{*}{ 콩 } & 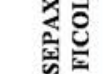 & 总 & $\ddot{~ g ొ ~}$ & $\stackrel{d}{g}$ & $\stackrel{\circ}{\circ}$ & 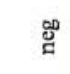 & : & $\stackrel{\circ}{\circ}$ & $\stackrel{\circ}{\circ}$ & $\stackrel{g}{g}$ & 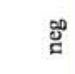 & $\stackrel{\text { g }}{\circ}$ \\
\hline & 旅 & 吕 & $\ddot{g}$ & $\ddot{~ घ ొ ~}$ & $\stackrel{\circ}{\circ}$ & $\ddot{g}$ & $\stackrel{\circ}{\circ}$ & : & $\stackrel{\circ}{\circ}$ & $\ddot{~}$ & ஜొ & $\stackrel{\circ}{\circ}$ \\
\hline & $\sum_{z}^{m}$ & $\begin{array}{l}\text { : } \\
\text { : }\end{array}$ & 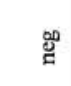 & 吕 & 莒 & $\ddot{~}$ & : & : & : & $\ddot{q}$ & $\stackrel{\text { gొ }}{g}$ & $\stackrel{\text { : }}{\circ}$ \\
\hline \multirow{5}{*}{ ㅎㅁㅁ } & 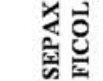 & $\stackrel{\text { : }}{\circ}$ & $\ddot{g}$ & $\ddot{~}$ & $\stackrel{\text { : }}{\circ}$ & $\stackrel{\circ 0}{\rightleftarrows}$ & : & : & $\stackrel{\text { : }}{\circ}$ & gొ & $\stackrel{\text { gొ }}{g}$ & : \\
\hline & 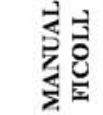 & $\stackrel{\circ}{\circ .}$ & $\ddot{~}$ & $\stackrel{g}{\square}$ & $\stackrel{\circ}{\circ .}$ & $\ddot{g}$ & 。̆ & 。̆. & $\stackrel{\circ}{\circ}$ & $\ddot{g}$ & $g ొ$ & $\stackrel{\circ}{\circ}$ \\
\hline & $\sum_{z}^{n}$ & $\stackrel{\circ}{\circ}$ & $\ddot{~}$ & $\stackrel{\sharp 0}{g}$ & $\stackrel{\circ}{\circ}$ & $\ddot{~}$ & $\stackrel{\circ}{\circ}$ & 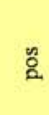 & $\stackrel{\circ}{\circ}$ & $\stackrel{\square}{\square}$ & 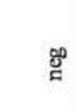 & 。 \\
\hline & 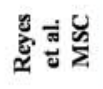 & $\vdots$ & & $\frac{80}{d 0}$ & $\stackrel{\circ}{\circ}$ & $\stackrel{g}{g}$ & 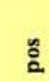 & 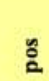 & مه & & $\stackrel{80}{E}$ & : \\
\hline & & 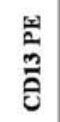 & 苞泀 & 虽 & 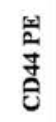 & 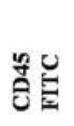 & 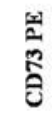 & 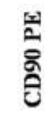 & 号 & 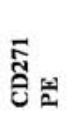 & 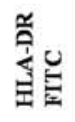 & 选 \\
\hline
\end{tabular}


Table 4: Incidence of MSC in native bone marrow

\begin{tabular}{l|ccccccc}
$\begin{array}{l}\text { Native Bone } \\
\text { Marrow }\end{array}$ & $\begin{array}{c}\text { Bruder } \\
1994\end{array}$ & $\begin{array}{c}\text { Prockop } \\
2000\end{array}$ & $\begin{array}{c}\text { Campangoli } \\
2001\end{array}$ & Wexler 2003 & Gangji & $\begin{array}{c}\text { Hernigou } \\
2004\end{array}$ & $\begin{array}{c}\text { Kasten } \\
2005\end{array}$ \\
\hline $\begin{array}{l}\text { MSC/ } 1 \mathrm{x} 10^{6} \\
\text { nucleated cells } \pm\end{array}$ & 10 & $30 \pm 8$ & $13 \pm 4$ & 33 & $9.2 \pm 9$ & $33 \pm 8$ & $7.14 \pm 5.8$ \\
SD & & & & & & &
\end{tabular}

of sufficient numbers of MSC and concentration of the MSC fraction in a reduced volume that can be injected (Hernigou et al., 2005). The current study demonstrated that there are relevant differences of MSC yield depending on the isolation protocol. In our experimental setting, the SEPAX VOL RED protocol showed the highest concentration capacity of MSC.

The feasibility of MSC concentration without laboratory facilities, e.g. with a portable, fully automated and closed centrifuge, is an important issue. Such a device would enable the physician to apply stem cell therapies in medical centres that do not have scientific laboratories. In addition, this system could lower costs and reduces the risk of infection. The SEPAX system (SEPAX, Biosafe) is a centrifuge which is a closed and fully automated system that is typically used to separate umbilical cord blood fractions under sterile conditions. BM separation may be achieved by specially adapted programs by use of a volume reduction or a Ficoll modus. The outcome shows that the standard method by use of a Ficoll gradient in the laboratory has a relevant loss of MSC compared to the frequency of MSC in native bone marrow. If the MSC are used in a cell culture, the disadvantage of MSC loss during the Ficoll procedure is counterbalanced by a homogenous and purified fraction of MNC that can easily be expanded. If, however, there is no expansion step, the initial MSC yield is essential. The SEPAX system could achieve the highest amount of MSC with the volume reduction protocol that separates the NC cell fraction. Since the MSC cannot easily be identified within the NC fraction without additional laboratory analysis, the complete $\mathrm{NC}$ fraction has to be used, i.e. with all white blood cells. There is no evidence whether the injection of a mixed cell population of nuclear cells influences performance (Gangji et al., 2004; Hernigou et al., 2005). One could postulate that the disintegration of white blood cells might cause an inflammation reaction with negative side effects (Hayashi et al., 2003). On the other hand, cell signalling and interaction with other progenitor cells within the $\mathrm{NC}$ fraction might be beneficial (Noth et al., 2007). Friedstein et al. showed that in cultures from mouse bone marrow plated at low cell density, CFU-F failed to develop unless the cultures were supplemented with irradiated feeder cells. Colony-stimulating activity was produced by irradiated bone marrow and spleen cells and by platelets, was dose dependent, not species specific and was maximal at high serum concentration. Consequently, a mixture of mononuclear cells, lymphocytes and polynuclear

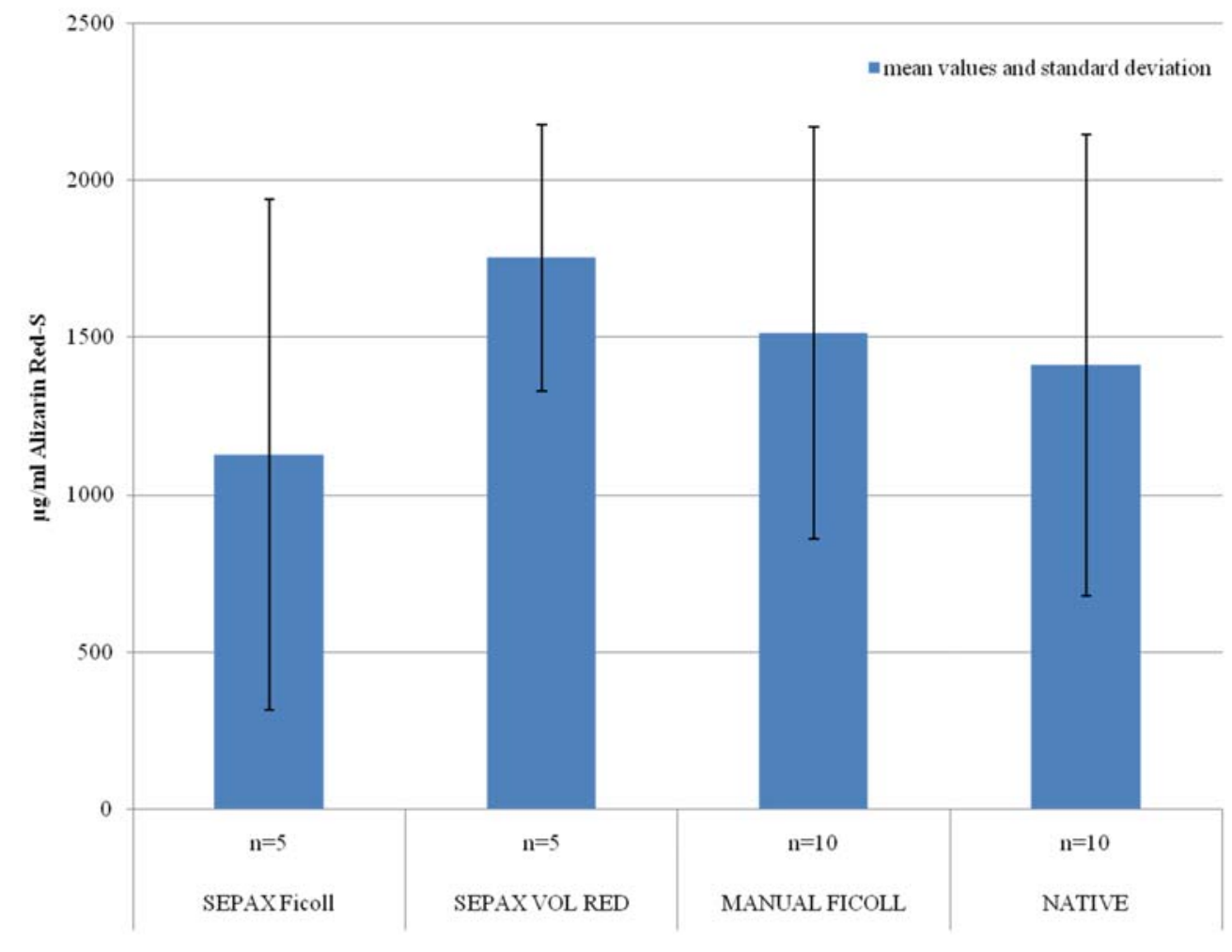

Figure 7: The osteogenic differentiation was assessed by the amount of calcification in the alizarin-red staining. There was a trend to higher values in the SEPAX VOL RED group without reaching significance. The high standard deviations reflect a known high donor variability. 
leukocytes might support the growth of CFU-F in culture (Friedenstein et al., 1992). This could explain the improved MSC yield from the VOL RED group. It would also explain why the NATIVE group, which consists of unprocessed, whole bone marrow, has higher MSC yields compared with FICOLL treated groups. Future studies will have to address this issue in vivo. Our results demonstrate that, in vitro, the MSC that were obtained by the VOL RED protocol have equal proliferation and mesenchymal plasticity capacities as the Ficoll and native BM groups.

Another important issue is the output volume; in the SEPAX FICOLL group, the output volume of the automated centrifuge was $45 \mathrm{ml}$. This relatively high volume is difficult to inject, for instance, into a femoral head or a non-union. In our experience, only volumes of $20 \mathrm{ml}$ maximum could safely be injected in the region of interest. Because the output volumes were different in the distinct protocols, the amounts of MSC were normalized to the volume of initially available BM volume to achieve comparable outcomes.

Generally speaking, there are promising results with the instant use of MSC to regenerate tissues. In the field of cardiology, percutaneous intramyocardial and intracoronary administration of MSC to patients after acute myocardial infarction is being investigated clinically (Nyolczas et al., 2007) because experimental studies favoured the use of MSC in this disease (Boomsma et al., 2007; Grogaard et al., 2007; Stamm et al., 2007; Tran et al., 2007; Wang et al., 2007). In orthopaedic surgery, Hernigou and co-workers treated tibial pseudoarthrosis with MSC injections (Hernigou et al., 2005). MSC were obtained by use of a volume reduction procedure in a laboratory centrifuge. Consequently, this procedure has the disadvantage that it is not done in the operating room; it is not done in a closed system, but in a separate laboratory facility. In this study, $300 \mathrm{ml}$ of BM were concentrated to approximately $20 \mathrm{ml}$ output volume containing $2.58 \times 10^{3}$ $\mathrm{MSC} / \mathrm{ml}$ and the authors observed healing in 53 out of 60 patients (Hernigou et al., 2005). The aspirates contained an average of $612 \mathrm{MSC} / \mathrm{cm}^{3}$ (SD 134) before concentration and an average of 2579 progenitors $/ \mathrm{cm}^{3}$ (SD 1121) after concentration. Consequently, the number of MSC was increased by a factor of 4.2. In our setting, the SEPAX VOL RED protocol concentrated the MSC by a factor of 14. Consequently, the concentration capacity of the closed SEPAX centrifuge was more efficient. Gangji et al. used a volume reduction protocol to decrease a BM aspirate of approximately $400 \mathrm{ml}$ to $51 \mathrm{ml}$ (SD 1.8 ) to significantly slow down the progression of avascular necrosis of the femoral head (Gangji et al., 2004). The mean number of leucocytes injected was $2.0 \times 10^{9}$ (SD 0.3) and there were $9.2 \mathrm{MSC} / 1 \times 10^{6} \mathrm{NC}$. In the current study, the incidence of MSC per million nucleated cells was similar to the one by Gangji et al. but lower as reported by others (Table 4). This lower number might be explained by a less effective aspiration technique of the BM (Muschler et al., 1997). It seems essential to use several puncture sites of the iliac crest at different depths with a distance of about 2-3 cm and to aspirate only the first couple of millilitres that have the highest incidence of MSC with a high suction (Muschler et al., 1997). Furthermore, differences between the expansion media, especially the amount and quality of FCS, can strongly influence the incidence of CFU-F (Castro-Malaspina et al., 1980). This means that an increase from $2 \%$ to $20 \% \mathrm{FCS}$ in the medium can perhaps quadruple the incidence of CFU-f (Castro-Malaspina et al., 1980).

Another issue regarding the portable centrifuge is the starting volume: The efficiency MSC enrichment by the VOL RED method is dependent on the starting volume of the bone marrow. In the phase 1 study using $30 \mathrm{ml} \mathrm{BM}$, VOL RED improved CFU-F formation only slightly above the NATIVE, unprocessed group, whereas using $300 \mathrm{ml}$ in phase 2, a 14-fold increase is observed. This means that small volumes should not be used for a clinical application, but volumes of e.g. 200-300 $\mathrm{ml}$ to get a sufficient number of progenitors to start with and a sufficient concentration of progenitors.

\section{Conclusion}

The use of the volume reduction protocol of the centrifuge allows for a higher concentration of MSC than the Ficoll procedures without altering the quality of the MSC. These results justify further evaluation of the centrifuge for instant MSC therapy on-site.

\section{Acknowledgements}

We would like to thank the Dr. hc. Robert Mathys Foundation for scientific and financial support. Furthermore, we would like to thank Biosafe for their technical support.

\section{References}

Boomsma RA, Swaminathan PD, Geenen DL (2007) Intravenously injected mesenchymal stem cells home to viable myocardium after coronary occlusion and preserve systolic function without altering infarct size. Int J Cardiol 122: $17-28$.

Bruder SP, Fink DJ, Caplan AI (1994) Mesenchymal stem cells in bone development, bone repair, and skeletal regeneration therapy. J Cell Biochem 56: 283-294.

Bruder SP, Kraus KH, Goldberg VM, Kadiyala S (1998) The effect of implants loaded with autologous mesenchymal stem cells on the healing of canine segmental bone defects. J Bone Joint Surg Am 80: 985-996.

Campagnoli C, Roberts IA, Kumar S, Bennett PR, Bellantuono I, Fisk NM (2001) Identification of mesenchymal stem/progenitor cells in human firsttrimester fetal blood, liver, and bone marrow. Blood 98: 2396-2402.

Castro-Malaspina H, Gay RE, Resnick G, Kapoor N, Meyers P, Chiarieri D, McKenzie S, Broxmeyer HE, Moore MA (1980) Characterization of human bone marrow fibroblast colony-forming cells (CFU-F) and their progeny. Blood 56: 289-301. 
Friedenstein AJ, Latzinik NV, Gorskaya Y, Luria EA, Moskvina IL (1992) Bone marrow stromal colony formation requires stimulation by haemopoietic cells. Bone Miner 18: 199-213.

Gangji V, Hauzeur JP, Matos C, De M, V, Toungouz M, Lambermont M (2004) Treatment of osteonecrosis of the femoral head with implantation of autologous bonemarrow cells. A pilot study. J Bone Joint Surg Am 86-A: 1153-1160.

Grogaard HK, Sigurjonsson OE, Brekke M, Klow NE, Landsverk KS, Lyberg T, Eriksen M, Egeland T, Ilebekk A (2007) Cardiac accumulation of bone marrow mononuclear progenitor cells after intracoronary or intravenous injection in pigs subjected to acute myocardial infarction with subsequent reperfusion. Cardiovasc Revasc Med 8: 21-27.

Hayashi Y, Sawa Y, Fukuyama N, Miyamoto Y, Takahashi T, Nakazawa H, Matsuda H (2003) Leukocytedepleted terminal blood cardioplegia provides superior myocardial protective effects in association with myocardium-derived nitric oxide and peroxynitrite production for patients undergoing prolonged aortic crossclamping for more than 120 minutes. J Thorac Cardiovasc Surg 126: 1813-1821.

Hernigou P, Beaujean F (2002) Treatment of osteonecrosis with autologous bone marrow grafting. Clin Orthop Relat Res 14-23.

Hernigou P, Poignard A, Beaujean F, Rouard H (2005) Percutaneous autologous bone-marrow grafting for nonunions. Influence of the number and concentration of progenitor cells. J Bone Joint Surg Am 87: 1430-1437.

Kasten P, Vogel J, Luginbuhl R, Niemeyer P, Tonak M, Lorenz H, Helbig L, Weiss S, Fellenberg J, Leo A, Simank HG, Richter W (2005) Ectopic bone formation associated with mesenchymal stem cells in a resorbable calcium deficient hydroxyapatite carrier. Biomaterials 26/ 29: 5879-5889.

Losordo DW, Schatz RA, White CJ, Udelson JE, Veereshwarayya V, Durgin M, Poh KK, Weinstein R, Kearney M, Chaudhry M, Burg A, Eaton L, Heyd L, Thorne T, Shturman L, Hoffmeister P, Story K, Zak V, Dowling D, Traverse JH, Olson RE, Flanagan J, Sodano D, Murayama T, Kawamoto A, Kusano KF, Wollins J, Welt F, Shah P, Soukas P, Asahara T, Henry TD (2007) Intramyocardial transplantation of autologous CD34+ stem cells for intractable angina: a phase I/IIa double-blind, randomized controlled trial. Circulation 115: 3165-3172.

Muschler GF, Boehm C, Easley K (1997) Aspiration to obtain osteoblast progenitor cells from human bone marrow: the influence of aspiration volume. J Bone Joint Surg Am 79: 1699-1709.

Noth U, Reichert J, Reppenhagen S, Steinert A, Rackwitz L, Eulert J, Beckmann J, Tingart M (2007) [Cell based therapy for the treatment of femoral head necrosis]. Orthopäde 36: 466-471.

Nyolczas N, Gyongyosi M, Beran G, Dettke M, Graf S, Sochor H, Christ G, Edes I, Balogh L, Krause KT, Jaquet K, Kuck KH, Benedek I, Hintea T, Kiss R, Preda I, Kotevski V, Pejkov H, Dudek D, Heba G, Sylven C, Charwat S, Jacob R, Maurer G, Lang I, Glogar D (2007)
Design and rationale for the Myocardial Stem Cell Administration After Acute Myocardial Infarction (MYSTAR) Study: a multicenter, prospective, randomized, single-blind trial comparing early and late intracoronary or combined (percutaneous intramyocardial and intracoronary) administration of nonselected autologous bone marrow cells to patients after acute myocardial infarction. Am Heart J 153: 212-217.

Prockop DJ, Azizi SA, Colter D, Digirolamo C, Kopen G, Phinney DG (2000) Potential use of stem cells from bone marrow to repair the extracellular matrix and the central nervous system. Biochem Soc Trans 28: 341-345.

Quarto R, Mastrogiacomo M, Cancedda R, Kutepov SM, Mukhachev V, Lavroukov A, Kon E, Marcacci M (2001) Repair of large bone defects with the use of autologous bone marrow stromal cells. N Engl J Med 344: 385-386.

Reyes M, Lund T, Lenvik T, Aguiar D, Koodie L, Verfaillie CM (2001) Purification and ex vivo expansion of postnatal human marrow mesodermal progenitor cells. Blood 98: 2615-2625.

Stamm C, Kleine HD, Choi YH, Dunkelmann S, Lauffs JA, Lorenzen B, David A, Liebold A, Nienaber C, Zurakowski D, Freund M, Steinhoff G (2007) Intramyocardial delivery of CD133+ bone marrow cells and coronary artery bypass grafting for chronic ischemic heart disease: safety and efficacy studies. J Thorac Cardiovasc Surg 133: 717-725.

Stanford CM, Jacobson PA, Eanes E, Lembke LA, Midura RJ (1995) Rapidly forming apatitic mineral in an osteoblastic cell line (UMR 106_01 BSP). J Biol Chem 270: 9420-9428.

Tran N, Franken PR, Maskali F, Nloga J, Maureira P, Poussier S, Groubatch F, Vanhove C, Villemot JP, Marie PY (2007) Intramyocardial Implantation of bone marrowderived stem cells enhances perfusion in chronic myocardial infarction: dependency on initial perfusion depth and follow-up assessed by gated pinhole SPECT. J Nucl Med 48: 405-412.

Vogel JP, Szalay K, Geiger F, Kramer M, Richter W, Kasten P (2006) Platelet-rich plasma improves expansion of human mesenchymal stem cells and retains differentiation capacity and in vivo bone formation in calcium phosphate ceramics. Platelets 17: 462-469.

Wang T, Tang W, Sun S, Ristagno G, Huang Z, Weil MH (2007) Intravenous infusion of bone marrow mesenchymal stem cells improves myocardial function in a rat model of myocardial ischemia. Crit Care Med 35: 2587-2593.

Wexler SA, Donaldson C, Denning-Kendall P, Rice C, Bradley B, Hows JM (2003) Adult bone marrow is a rich source of human mesenchymal 'stem' cells but umbilical cord and mobilized adult blood are not. Br J Haematol 121: 368-374.

Winter A, Breit S, Parsch D, Benz K, Steck E, Hauner H, Weber RM, Ewerbeck V, Richter W (2003) Cartilagelike gene expression in differentiated human stem cell spheroids: a comparison of bone marrow-derived and adipose tissue-derived stromal cells. Arthritis Rheum 48: 418-429. 